\title{
COELHO NETO MELODRAMÁTICO: ESTUDO DOS DRAMAS IRONIA (1898) E O DINHEIRO (1912)
}

\author{
Suzane Morais da VEIGA \\ Universidade Federal do Estado do Rio de Janeiro \\ suzanemveiga@yahoo.com.br
}

\begin{abstract}
Resumo: Durante a conturbada Belle Époque no Brasil, que no Rio de Janeiro se estende aproximadamente dos anos de 1890 a 1930, houve uma efervescência intelectual e artística na cidade, contando com a participação de ilustres figuras literárias que mantinham com a Europa uma relação de contínua troca cultural, época em que, segundo o historiador Jeffrey Needell, uma elite carioca procurava assemelhar-se ao modo de vida europeu, notadamente o de Paris. É neste contexto que florescem no cenário teatral e literário fluminense formas artísticas nascidas na França como o melodrama, gênero relido e reinterpretado por hábeis autores nacionais a exemplo de Coelho Neto (1864-1934), cuja produção serve de corpus para este trabalho, especificamente as peças Ironia (1898) e O Dinheiro (1912).
\end{abstract}

Palavras-chave: Coelho Neto. Melodrama. Belle Époque.

Abstract: During the eventful Belle Époque in Brazil, which in Rio de Janeiro unfolds around the 1890 s to 1930 s, there was an intellectual and cultural agitation in the city, with the participation of great literary figures which had with Europe a continuous relationship of cultural exchange, a period when, according to Jeffrey Needell, a "carioca" high society sought to get familiar with an European way of life, especially that of Paris. It is in this context that arise in the theatrical and literary scenario of Rio de Janeiro artistic forms born in France, like melodrama and feuilleton novel, genres reinterpreted by the clever minds of national authors such as Coelho Neto (1864-1934) whose production serves as corpus for this paper, specifically the pieces Ironia (1898) and $O$ dinheiro (1912).

Keywords: Coelho Neto. Melodrama. Belle Époque.

\section{Introdução}

A ideia norteadora para a realização do presente artigo surgiu de uma reflexão sobre as condições de produção do fazer artístico na virada do século XIX para o século XX no Rio de Janeiro e os modos de articulação das artes com outros campos de força da época. Interessava-me, sobretudo, traçar um recorte histórico-temporal procurando alcançar um melhor entendimento acerca dos elementos que aproximavam aquela

\begin{tabular}{|l|l|l|l|l|}
\hline Pensares em Revista & São Gonçalo, RJ & n. 1 & $169-185$ & jul.-dez. 2012 \\
\hline
\end{tabular}


produção de uma literatura essencialmente brasileira e "popular"1 nos temas tratados e em seu modus operandi, contribuindo para um significativo aumento do interesse dos jovens escritores a ingressarem no mundo das letras e das artes cênicas, dentre eles Coelho Neto, propiciando um verdadeiro movimento artístico (e político) na então capital federal.

Entretanto, uma questão estava ainda a se colocar como hipótese para essa pesquisa: qual a posição do teatro melodramático dentro de uma esfera cultural carioca que aos poucos começava a produzir o seu próprio mercado artístico/cultural?

Para isso é preciso analisar os processos que deste fenômeno resultam: o aumento expressivo do público consumidor; o desenvolvimento de certa autonomia (e valorização) de um fazer nacional em relação ao que vinha de fora; a expansão e potencialização dos instrumentos de veiculação dos espetáculos e uma crescente procura por jovens artistas nacionais em decorrência da grande demanda por novidades que chamassem a atenção do público.

Logo, o presente trabalho se propõe a analisar como esse gênero teatral foi "bemsucedido" no Rio de Janeiro de fim de século, quais foram efetivamente as condições de produção desse gênero, além de focalizar a relação dessa forma dramática na obra do escritor Coelho Neto, através da análise de duas de suas peças de repercussão da época: O dinheiro (1912) e Ironia (1898). Observar-se-á, dessa maneira, como o imaginário melodramático está presente no teatro produzido pelo escritor fluminense, considerando os apontamentos essenciais de Peter Brooks, cujos textos auxiliam a presente análise.

\section{Melodrama: um gênero híbrido de caráter essencialmente popular}

O homem possui um instinto com relação ao qual, a despeito de sua inesgotável vitalidade, nem os historiadores, nem os psicólogos, nem os que se ocupam da estética, disseram até aqui a menor palavra. Refiro-me ao instinto da transfiguração, ao instinto de transformar as aparências ofertadas pela natureza em alguma outra coisa..., numa palavra, ao instinto cuja essência se revela no que eu chamo a teatralidade. Eis aí o sentido de nossa existência... Nascemos todos com este sentimento na alma, somos todos seres essencialmente teatrais.

1 A noção de popular é evocada neste texto em relação ao consumo de determinada produção literária por grande parte da população, bem como a sua democratização.

\begin{tabular}{|l|l|l|l|l|}
\hline Pensares em Revista & São Gonçalo, RJ & n. 1 & $169-185$ & jul.-dez. 2012 \\
\hline
\end{tabular}


Ao evocarmos o termo melodrama, é possível que nos lembremos dos lacrimosos enredos das novelas da televisão brasileira, nos quais as mocinhas sempre sofrem penosamente até o final glorioso; ou dos grandes roteiros cinematográficos de Hollywood, repletos de cenas de insólita aventura e de romances recheados de fugas e promessas de amor; dos comerciais de TV de propaganda publicitária que, a fim de venderem algum produto, lançam mão de uma série de estratagemas para nos emocionar através de um continuado derramamento de sentimentos; e até mesmo das conversas cotidianas, quando deparamos com alguma cena de exagerada expressão afetiva, e não hesitamos em dizer: "Que melodrama!".

Assim, esse gênero exibe-se para a presente análise como fruto de uma curiosa diversificação de usos e significados ao longo de sua história, enquanto gênero literário e teatral. Ele tem ainda, como base de efeito, um forte apelo afetivo-emocional por meio do qual, no transbordamento de sentimentos, opera-se um processo "catártico", cuja finalidade é a persuasão sobre certo aspecto destacado pelo enredo, a ser defendido ou (re) afirmado. Com isso, foram múltiplos os usos de elementos melodramáticos por escritores, dramaturgos e grupos teatrais do século XIX, período de seu florescimento enquanto gênero na França, e que continuam a ser usados nos dias atuais pela indústria televisiva e pelas mídias em geral, devido à sua singular capacidade de atingir grandes massas de espectadores, em geral, públicos bastante heterogêneos.

O primeiro viés a ser verificado na análise do melodrama é o histórico, que trata dos seus processos formativos, cuja constituição acena para um longo percurso de cruzamento de uma série de outras experiências (teatrais) que concorreram para a gênese do gênero. Uma das referências mais fortes é a Commedia dell'arte, tipo de teatro popular que recebeu várias alcunhas ao longo de sua história como "teatro improvisado" ou "teatro de puro gesto, sem texto".

Assim, o próprio contexto no qual esta forma teatral surge remete a um esforço por parte daqueles artistas em tornar o teatro acessível a todos. A Commedia dell'arte exercia fascínio sobre os espectadores por seus enredos aventureiros e peripécias: “(...)

2 Citado por Borba Filho (1950, p. 12).

\begin{tabular}{|l|l|l|l|l|}
\hline Pensares em Revista & São Gonçalo, RJ & n. 1 & $169-185$ & jul.-dez. 2012 \\
\hline
\end{tabular}


enredos loucos baseados em quiproquós, imbróglios, raptos, disfarces e outras peripécias que deixavam o espectador sem fôlego e sempre na expectativa" (MEYER, 1967, p. 27). Os atores viajavam em uma carroça, utilizada como transporte e cenário durante as improvisações, apresentando-se em feiras ou em praças públicas de várias cidades. Cada qual com a sua máscara, que caracterizava a sua personagem fixa, ${ }^{3}$ formavam trupes itinerantes de atores profissionais inaugurando um novo estilo e uma nova linguagem teatrais, com ampla utilização de efeitos cômicos e irônicos:

As companhias de commedia dell'arte começaram a se formar na segunda metade do século XVI, na Itália; atingiram o auge de popularidade e prestígio no século XVII, e entraram em declínio a partir do século XVIII. Como gênero de teatro, a commedia dell'arte atravessou quase três séculos e vários países da Europa, exercendo fascínio e influência em diversos dramaturgos, encenadores e atores. Shakespeare, Lope de Veja, Molière, Beaumarchais, Meyerhold, JeanLouis Barrault, Marcel Marceau e Dario Fo são alguns de seus inúmeros herdeiros. (...) Ao entrar para uma companhia cada ator oferecia como capital suas experiências, conhecimentos e habilidades. (...) Quando bufões e histriões, artistas solitários, herdeiros da tradição cômica medieval, integravam-se numa companhia, levavam consigo o seu repertório - canções, pantomimas, monólogos - e as técnicas de seu ofício. Este, entretanto, deveria ser modificado e adaptado ao amplo repertório das companhias (MATERNO, 1994, p. 49-50).

Outra faceta histórica importante e fundamental no estabelecimento do melodrama como forma eminentemente popular teria sido a pantomima, uma modalidade cênica que almejava alcançar o máximo de expressão de seus intérpretes, tendo forte vínculo com a arte da mímica - em uso até hoje como artifício cênico por vários profissionais que primam pela excelência da manifestação expressiva do corpo, como palhaços, cômicos, atores e bailarinos. Esses artistas utilizam-se, assim, de um variado repertório de movimentos corporais, expressões faciais, figurinos, ornamentos, e potentes maquiagens que ajudam a ressaltar a significação das diferentes contrações do rosto e de gestos.

3 As diversas máscaras da Commedia dell'arte forneciam a expressão facial e protótipo da personagem, por exemplo: sorrindo - esperto; sobrancelhas tensas - malvado. Cada expressão estava diretamente relacionada a um corpo específico, cuja personagem dotada de personalidade possuía uma função ímpar dentro do enredo. Algumas dessas personagens estão bastante presentes no imaginário cultural brasileiro, como a Colombina (mocinha), o Arlequim (herói sabido), Pantalone (velho avarento), dentre outros.

\begin{tabular}{|l|l|l|l|l|}
\hline Pensares em Revista & São Gonçalo, RJ & n. 1 & $169-185$ & jul.-dez. 2012 \\
\hline
\end{tabular}


Assim, ao iniciarmos a análise do melodrama sob esse prisma histórico, ressaltase o fato de que desde sua origem o melodrama apresentou uma fazer eminentemente cênico (voltado para a cena) e que assumiu uma forma de se fazer teatro em que o jogo dos atores no palco e o caráter visual do espetáculo são mais importantes do que o texto: "Devido ao seu gosto pelas situações o melodrama foi uma das primeiras formas teatrais a se afastar deliberadamente da escrita tradicional do teatro, preferindo uma linguagem puramente cênica: aquela da ação e das imagens" (THOMASSEAU, 1989, p. 112).

O melodrama teria nascido, como gênero teatral, no fim do século XVIII, na França, através da junção dessas manifestações da tradição popular e teria sido utilizado como ferramenta política e social, conforme estudo de Regina Horta Duarte (1995, p. 280), para opor-se à cultura aristocrática, tornando-se conhecido no século XIX através dos teatros de boulevard $^{4}$ e da disseminação de espaços públicos propícios para entretenimento e diversão, atraindo, assim, artistas e profissionais de teatro. Começava a se formar, dessa maneira, na França, um público consumidor de teatro, movimentando um mercado que demandava autores e companhias preocupados em agradar ao maior contingente de público possível, vendo no melodrama um gênero que facilmente atrai multidões e gera grandes bilheterias. Segundo Paulo Merísio (2006, p. 51), “essa atenção aos desejos do público consumidor espelha o movimento empreendido pelos produtores do melodrama no sentido de satisfazer seu público, com a intenção de garantir o retorno do investimento".

No Brasil, o melodrama surge em condições semelhanças às da França, em um período conturbado da sociedade brasileira do início do século XIX, em meio a revoltas como a Conjuração Baiana (1798) e a Inconfidência Mineira (1789), cujos manifestantes (influenciados pelos ideais da Revolução Francesa e Independência dos Estados Unidos) pretendiam a independência econômica e política do Brasil. O gênero

\footnotetext{
4 Conforme nota de Paulo Merísio (2006, p. 46), "segundo Patrice Pavis, o boulevard era, no século XIX, o famoso boulevard do crime (destruído em 1862), os boulevards Saint-Martin e du Temple, onde os palcos da Gaité (Alegria), do Ambigú (Ambíguo) e dos Funambules (Funâmbulos) eram os teatros de inúmeros delitos e aventuras sentimentais: ali se representavam melodramas, pantomimas, espetáculos de féerie e de acrobacia, comédias burguesas (Scribe) já criticadas por artistas e intelectuais da época. O boulevard conheceu, antes da Segunda Guerra Mundial, seu período mais faustoso, com uma vertente cômica vaudevillesca e uma vertente séria e psicológica (Berstein). Depois de 1930, o boulevard passa a ter qualidade: Guitry, Bourdet, Bataille, mais tarde Anouilh, Aymé, Achard e Marceau (Cf. PAVIS, 1999, p. 380)".
}

\begin{tabular}{|l|l|l|l|l|}
\hline Pensares em Revista & São Gonçalo, RJ & n. 1 & $169-185$ & jul.-dez. 2012 \\
\hline
\end{tabular}


melodramático permanece nos palcos brasileiros e, principalmente, cariocas, com significativo sucesso de plateia, tendo grande repercussão na época da transição do Império para a tão sonhada República. Podemos destacar, nesse sentido, certa transformação da sociedade brasileira da época numa crescente "sociedade de consumo" que aos poucos atraía e produzia uma cultura de massa através da incorporação do conjunto das camadas populares, de forma numerosa.

Outro elemento importante do gênero é sua capacidade de "incorporar" novidades e fatos externos à sua produção, sendo o melodrama uma forma de atuação cênica que se apropria de elementos de improvisação, o que proporciona uma ampla rede de associações e conexões no jogo dos atores em cena. Segundo aponta Ivete Huppes (2000, p. 23-25), à medida que o tempo passa, personagens feudais vão sendo substituídos por outros, burgueses, e os cenários rústicos cedem lugar a espaços urbanos.

Há ainda indícios de representações melodramáticas na Belle Époque até meados do século XX, contudo a influência de sua dramaturgia no teatro brasileiro é extensiva, presente até os dias atuais, devido à enorme expressividade de sua forma e ao forte apelo popular de sua linguagem. Paulo Merísio (2005, p. 16) associa a grande adesão ao gênero pelo teatro e pela literatura brasileiros ao sucesso da escola que imperava no início do século XIX no Brasil, o Romantismo.

Com a grande demanda pelo público por mais espetáculos, começou-se também a aumentar a procura de profissionais nesse campo, dando oportunidade a diversos artistas brasileiros de rivalizarem com os atores e companhias estrangeiras no Brasil, destacando-se o ator João Caetano (1808-1863), sendo o século XIX considerado o verdadeiro momento de expansão do teatro brasileiro, tendo o melodrama um papel fundamental nesse processo.

\section{O conceito de melodrama e melodramático segundo Peter Brooks}

Peter Brooks, no livro The melodramatic imagination: Balzac, Henry James, Melodrama and the mode of excess (1976), apresenta o melodramático como uma manifestação cultural e social, nascida da necessidade de expressão da burguesia

\begin{tabular}{|l|l|l|l|l|}
\hline Pensares em Revista & São Gonçalo, RJ & n. 1 & $169-185$ & jul.-dez. 2012 \\
\hline
\end{tabular}


francesa oitocentista pós-revolução, das obsessões e vontades latentes desse grupo dominante.

O melodrama seria então fruto de modos imaginativos que, segundo Brooks, reafirmam a sua permanência na modernidade ao centralizar em sua trama os receios e dificuldades da vida burguesa, como a família, o trabalho, e os valores morais e sociais. Além disso, é notável no melodrama a delimitação de uma estética peculiar, retomada como inspiração por artistas e grupos de teatro até os dias atuais:

Os modos imaginativos em que as formas culturais expressam as preocupações sociais e psicológicas dominantes sentiram que a categoria do melodramático precisava ser revivido pois apontava para - como nenhum outro termo pôde - uma certa complexidade de obsessões e escolhas estéticas centrais para nossa modernidade (BROOKS, 1976, viii). (Nossa tradução).

Brooks, dessa maneira, situa o melodrama como um novo gênero, constituído no momento da decadência do antigo regime na França, em um período de intensa discussão de elementos éticos e sociais, definindo-o como

[...] uma estética expressionista, em nosso entendimento de suas afinidades com certas formulações psicoanalíticas, em nossa atenção ao uso da música e outros signos não-verbais em suas práticas, em nossas histórias de suas origens nas revoluções burguesas do final do século XVIII (BROOKS, 1976, p. 50).

Já o melodramático poderia ser conceituado em termos literários como a voz do narrador divagando, levantando hipóteses, sobre os personagens e sobre o enredo. No palco, são os momentos de forte tensão emocional vividos pelas personagens principais, em que se confrontam e dialogam de forma retórica, invariavelmente em uma discussão onde um quer convencer o outro sobre algo, e também levar o leitor a crer neste ou naquele encaminhamento da trama, podendo este ser surpreendido ao longo da estória.

Esses efeitos utilizados na narrativa dramática do melodrama funcionam como "alavancas" impulsionando o enredo, "costurando" os atos e prendendo a atenção do espectador sempre em busca de chegar ao desfecho de determinada peripécia, ou de certa "crise" dos personagens. São tramas de fácil engajamento da plateia por

\begin{tabular}{|l|l|l|l|l|}
\hline Pensares em Revista & São Gonçalo, RJ & n. 1 & 169-185 & jul.-dez. 2012 \\
\hline
\end{tabular}


provocarem uma notável empatia ao se apresentar rica de acontecimentos e de fácil acesso a todos os tipos de público, desde os mais populares até os considerados de gosto "refinado".

Ainda assim, Aluísio Azevedo (1857-1913), admirador do teatro popular e irmão de Artur Azevedo (1855-1908), teve de responder às críticas ao teatro "ligeiro" da época afirmando que esse tipo de peças são "dramas de enredo" e não "dramas de reflexão, de pensamento" e que por isso requereriam do público menos atenção (FARIA, 2001, p. 581).

Alguns dramas eram como thrillers, devido ao rápido desenrolar da trama e às sucessivas descobertas que levam ao desfecho retumbante do drama, pensado para provocar no palco uma verdadeira apoteose no fim do espetáculo, uma das características do melodrama. Conforme afirma Ivete Huppes, o melodrama, ao afastarse do texto literário, privilegiando o jogo da cena, instituiu uma nova linguagem, que salientava a extensão máxima da ação e das imagens: "No melodrama a arte repousa quase que inteiramente sobre as situações, sobre a encenação, sobre o talento dos atores, afastando-se, portanto, do domínio do texto, que até então reinava absoluto" (2000, p. 101).

Assim, Peter Brooks demonstra em seu livro um rol de traços específicos ao melodrama, dentre os quais destacamos: o exagero do momento, o transtorno psíquico dos personagens principais, o uso de figuras hiperbólicas, os eventos grandiosos e irreversíveis, as relações mascaradas e as identidades enganosas, abduções, venenos lentos, sociedades secretas, parentescos misteriosos, a "moral oculta", ou seja: os sentimentos e aflições reprimidas na vida cotidiana e que afloram nos momentos de tensão da trama, o desejo de expressar tudo de uma vez só e as ações desmedidas.

\section{As reverberações do melodramático no drama Ironia (1898), de Coelho Neto}

A peça de nome Ironia foi um dos primeiros dramas escritos por Coelho Neto e teve sua estreia para o público carioca em 04 de Novembro de 1898. À época de sua apresentação, a peça foi recebida com entusiasmo pelo público e pela crítica teatral ao apresentar um "descortinamento dramático" do autor para as questões sociais e, no caso

\begin{tabular}{|l|l|l|l|l|}
\hline Pensares em Revista & São Gonçalo, RJ & n. 1 & $169-185$ & jul.-dez. 2012 \\
\hline
\end{tabular}


da peça citada, para o ofício do ator e para algumas das contradições do mercado artístico de então.

O enredo de Ironia inicia-se com a apresentação da personagem principal, Julieta, primeira atriz de um conceituado teatro cujo empresário, Zeferino, espécie de antagonista da estória, ávido por mais lucro provindo da bilheteria dos espetáculos, obriga os seus atores a trabalharem até o limite da exaustão, mesmo que estejam doentes ou com problemas na família. Desse modo, Julieta é mostrada, logo nas primeiras páginas do drama, como uma atriz de sucesso no dia de estreia de uma comedia ansiosamente aguardada pelo elenco do grupo de atores, dentre os quais ela é a primeira atriz, e também pelo público.

O cenário é o seu camarim, onde ela recebe flores, logo após o fim do primeiro ato da peça, de dois de seus maiores admiradores: Alfredo, poeta e "moço moreno que parece estrangeiro" e o senhor Comendador Salgueiro, "velho calvo" e prolixo (COELHO NETO, 2001, p. 32). Porém, o que pareceria apenas estado de ventura e felicidade na vida de Julieta é confrontado com a condição em que ela se encontra. Triste e preocupada, Julieta mal consegue disfarçar o descontentamento de não poder estar em casa cuidando do filho de um ano e meio, seriamente doente. Ela é, pois, obrigada pelo empresário ganancioso a continuar em cena aparentando alegria e leveza no palco, devido à atmosfera de humor da peça, apesar da angústia que sente.

É nesse momento que a mãe de Julieta chega ao camarim da filha, sob forte chuva, para implorar que ela volte para casa, pois o seu filho não para de chamar por seu nome - ele que, segundo ela, já está à beira da morte. A camareira, Clara, percebendo a gravidade da situação, procura avisar ao empresário sobre a presença da mãe, fazendo com que o ganancioso homem de negócios, numa manobra astuta, esconda a mãe da atriz atrás de um biombo, induzindo a atriz a voltar para o palco e continuar o espetáculo.

Porém, quando Julieta já está se encaminhando para o palco, de repente escuta o soluço desesperado de sua mãe que chora atrás do biombo. Assim, mãe e filha se encontram e se abraçam de forma comovente. Luciana, mãe da atriz, então, implora à filha que volte para casa para ver o filho, talvez pela última vez, rogando ao próprio empresário que a libere para ir para casa. O empresário, por sua vez, furioso com a

\begin{tabular}{|l|l|l|l|l|}
\hline Pensares em Revista & São Gonçalo, RJ & n. 1 & $169-185$ & jul.-dez. 2012 \\
\hline
\end{tabular}


situação, ameaça Julieta, afirmando que não é ele e sim o público que a obriga a ficar, o qual nesse entretempo já começa a manifestar impaciência pela demora da atriz no camarim.

Num desfecho "em aberto", a peça termina com a atriz voltando para o palco e Luciana, mãe de Julieta, voltando para casa com as flores que a filha recebera dos admiradores, supostamente para colocá-las no caixão do neto.

Como podemos perceber na descrição do drama, ele se apresenta como um texto altamente afetado, emocional, o que ajuda a criar empatia com o leitor/espectador através de um transbordamento de emoções e sensações, no qual elementos de um imaginário melodramático são utilizados na composição de um enredo comovente, bemestruturado e arrojado, tanto no tema como na forma de construção, que mistura aspectos do melodramático aliados aos requintes de uma dramaturgia aos moldes clássicos.

Ao observarmos a peça, vemos que se trata de um metadrama ou de metateatro ${ }^{5}$, onde os atores ${ }^{6}$ encenam os bastidores de sua própria prática enquanto atores, uma ousadia para a dramaturgia brasileira da época. A estória inicia-se in medias res, ou "no meio da estória", técnica literária que remete às grandes tragédias gregas, fazendo com que o leitor/espectador apenas tome consciência da narrativa na medida em que se familiariza com as personagens da trama e suas contradições e contingências.

Ironia apresenta, assim, um enredo que gira em torno de um único núcleo de ação, cuja tensão dramática baseia todo o desenrolar dos acontecimentos até o fim da peça que termina sem resolução, mas com uma tragédia iminente. Julieta, a exemplo de outras heroínas clássicas como Medeia e Antígona, tem de fazer a difícil escolha entre a honra, a família, a ética e as contingências sociais.

A obra, no entanto, conforme aponta Artur Azevedo (1898), não se encaixaria na acepção antiga de drama, pois falta a ela ação dramática, ou seja, desenvolvimento de peripécias, mudanças de estado da personagem ou novos acontecimentos ao longo da

5 Metadrama ou metateatro são termos que se aplicam às obras dramáticas que remetem para si próprias, enquanto textos de representação.

6 Distribuição original dos papéis de Ironia: Comendador Salgueiro - Sr. Ademar Barbosa Romeu; Empresário - Sr. Henrique de Holanda; Alfredo (poeta) - Sr. Estevão Ferrão; Julieta - D. Antonieta Saldanha da Gama; Luciana (mãe de Julieta) - D. Emília Barros Barreto; Clara (camareira) - D. Esmeralda Brandão (Cf. COELHO NETO, 2001).

\begin{tabular}{|l|l|l|l|l|}
\hline Pensares em Revista & São Gonçalo, RJ & n. 1 & $169-185$ & jul.-dez. 2012 \\
\hline
\end{tabular}


trama, bem como um desfecho. Esses fatores, porém, segundo o dramaturgo, não teriam interferido na grandeza do drama e nem em seu grande sucesso, afirmando ser louvável por parte do escritor Coelho Neto o fato de se privilegiar, na escrita de seus textos, a representação de uma atriz brasileira "tão maternal e digna de respeito" (1898). Apesar dos elogios e das boas críticas, Coelho Neto teria permanecido em silêncio perante o repentino sucesso de Ironia, a qual gozou de mais aceitação do que as investidas anteriores do autor nos gêneros do palco, com as peças Ártemis (1898) e Hóstia (1898) (Cf. COUTINHO, 2009).

Tudo no drama de Coelho Neto remete à questão moral implícita na obra: uma profissão que em um primeiro momento traria glamour e fama (e sendo ela a primeira atriz de uma casa lotada - o sonho de qualquer atriz iniciante) obriga Julieta a passar a maior parte do tempo longe do filho, que é, para ela, o mais importante na vida e que ela acaba por perder. Tudo na descrição do drama remete ao irônico da situação. As flores recebidas pelos admiradores são levadas pela mãe da atriz para supostamente serem levadas para o túmulo do filho; as gargalhadas da plateia e o choro de Julieta; o sofisticado camarim da atriz, bem como a grandeza acarretada pelo prestígio de ser a "estrela" do espetáculo contrastam com o estado de pobreza real de Julieta, a qual precisa do emprego para sobreviver.

Julieta: Vá mamãe. (Ao empresário) Podemos ir. (Já à porta, a Luciana) Até logo... (Detém-se um momento enxugando os olhos e segue, de arremetida)

Luciana: Minha pobre filha! (Ouve-se um rumor do pano que sobe. Palmas)

Comendador: É horrível, entende? Uma pobre mãe... (A Luciana) O carro está às suas ordens, entende? Às suas ordens...

Alfredo: Com licença... Adeus Clarinha. (Saindo com o Comendador) Ah a vida artística, Comendador (COELHO NETO, 2001, p. 45).

Esses elementos conjugados na trama de Ironia ajudam a provocar nos espectadores o despertar de emoções, cujo objetivo é a catarse desses sentimentos. Segundo Regina Horta Duarte (1995, p. 120), o cunho "didático" do melodrama remete à sua origem francesa do século XVIII, pós Revolução Industrial, em que surge uma nova classe (o proletariado), associado a um maior acesso das classes inferiores da

\begin{tabular}{|l|l|l|l|l|}
\hline Pensares em Revista & São Gonçalo, RJ & n. 1 & $169-185$ & jul.-dez. 2012 \\
\hline
\end{tabular}


população aos teatros, principalmente devido à ordem judicial de 1793 , que previa a abertura de novos teatros. Existe, assim, um caráter extremamente moralizante no seio da obra de Coelho Neto, ao confrontar valores como dignidade e ganância, amor e interesse, família e dinheiro, aspectos inerentes ao melodrama.

\section{As reverberações do melodramático no drama $O$ dinheiro (1912) de Coelho Neto}

O drama $O$ dinheiro, de Coelho Neto, publicado em 1915, compreende a fase madura do escritor, quando, segundo muitos de seus críticos, aperfeiçoou a sua escrita teatral com riqueza temática e requintes estilísticos (Cf. BRAGA, 2001).

Representado pela primeira vez em 12 de Novembro de 1912 pela Companhia Nacional Subvencionada, ${ }^{7} O$ dinheiro versa sobre os limites da ganância e da cobiça vividos por um casal em crise, e em cujo embate moral reside a proposta dramática da peça. "Testados" pela luxúria e promessa de riquezas de uma cidade igualmente corrompida, o Rio de Janeiro, o casal Lívia e Memede são apresentados logo no início do drama como um casal que vive de aparências e traições, descritos pela boca de outros dois personagens, o Brotas e o Paiva, dois companheiros de Mamede na boemia carioca. Invejosos, eles comentam a riqueza de Mamede, possivelmente obtida através de operações ilícitas com dinheiro público. Além disso, comentam o caso da amante de luxo que Mamede sustenta e ostenta a outros homens, além do possível impacto desse fato sobre a mulher dele, Lívia, imaginada por eles como igualmente traidora.

Quando Lívia e Mamede aparecem conversando nas páginas seguintes, tem-se a impressão de que são um casal normal, apenas em crise pela constante ausência do marido. Os dois vieram de uma cidade do interior e conseguiram, com esforço, certo conforto e posição social na capital, Rio de Janeiro. Porém, Lívia não estava feliz, pois notava que seu esposo era cada vez mais ausente e ganancioso. Além disso, desconfiava que ele mantinha uma amante.

Logo em seguida, Mamede pede a Lívia que receba um cliente seu em casa,

7 Distribuição original dos papéis de O dinheiro: Mamede - Sr. Antônio Ramos; Honório - Sr. Ferreira de Souza; Lupércio - Sr. Álvaro Costa; Ramiro - Sr. Castelo Branco; O Copeiro - Sr. Antônio Sampaio; Lívia - D. Maria Falcão; Venância - D. Gabriela Montani; Eva - D. Luiza de Oliveira; Cotinha - D. Marta de Souza.

\begin{tabular}{|l|l|l|l|l|}
\hline Pensares em Revista & São Gonçalo, RJ & n. 1 & $169-185$ & jul.-dez. 2012 \\
\hline
\end{tabular}


sozinha, alegando que ele não poderia permanecer, pois tinha que sair e fechar um negócio. Lívia, revoltada, clama pelo seu pudor de esposa, afirmando não ser do feitio de uma mulher honesta receber um homem em casa sozinha. Mamede retruca, dizendo que ela é e sempre será uma provinciana, pois as mulheres modernas não têm medo do que os outros podem falar. Mamede então sai e o homem chega. Ele se chama Honório e durante a conversa com Lívia revela-lhe que Mamede tem uma amante. A jovem senhora, em lágrimas, é então surpreendida por Honório que a beija repentinamente. Sentindo-se vendida pelo marido, Lívia arrebenta o colar de pérolas que usava.

Nesse momento, Mamede chega enquanto Honório vai embora e, vendo o colar espalhado pelo chão, imagina que a mulher o traiu. Indignado, Mamede pede explicações à mulher que, transtornada, o acusa de traição e corrupção. Mamede saca sua arma e num acesso de fúria atira em Lívia. A cena do desfecho do drama é a seguinte: Lívia correndo para fora da casa, pois conseguiu desviar-se da bala e Mamede bebendo na sala de estar dizendo: "É assim que um homem se perde".

Como podemos verificar, o enredo de $O$ dinheiro é permeado por elementos inerentes ao imaginário melodramático: traições, corrupção, vingança, armas e disputas em perfil "cinematográfico" com grandes desenlaces trágicos, ou, como no caso da peça, um twist ending, um desfecho inesperado que provoca suspense até o final que, por pouco, não termina em desenlace funesto.

Este é um drama que retrata a sociedade citadina, obcecada pela aparência, pelo dinheiro e pela manutenção do status social, em que Mamede expõe a própria mulher a um homem desconhecido em troca de um contrato de negócios, como afirma Cláudia Braga (2001, p. 24): “Aqui, Mamede, um homem cuja fortuna foi acumulada na intermediação de negócios com o governo, não hesita em expor a própria mulher como objeto de troca numa negociação que lhe traria enorme lucro". Além disso, o autor aponta neste drama para outros comportamentos em relação ao papel da mulher na sociedade ao mostrar um final em que, mesmo sob forte tensão dramática, a mulher consegue se desvencilhar daquele que a oprime, fugindo de uma relação que não a agrada mais.

O confronto ético e moral na discussão retórica de Lívia e Mamede encerra a problemática de $O$ dinheiro: será que o dinheiro compra tudo, até mesmo a dignidade de

\begin{tabular}{|l|l|l|l|l|}
\hline Pensares em Revista & São Gonçalo, RJ & n. 1 & $169-185$ & jul.-dez. 2012 \\
\hline
\end{tabular}


uma pessoa? Consumido pela ganância e pelo vício, Mamede, em contraste com a virtude defendida por Lívia, como moça honrada de origens humildes, pode expressar o conflito vivido pelo Rio de Janeiro da Belle Époque, que crescia de forma próspera, mas que, esquecida dos valores morais, conforme sustenta o desenvolvimento do drama, engendrava todo o tipo de vícios e luxúrias por parte de seus habitantes.

\section{Conclusão}

$\mathrm{Na}$ conjuntura do Brasil finissecular, o Rio de Janeiro passava por muitas transformações e se configurava aos poucos como um pólo econômico e cultural de referência nacional, num período conhecido como Belle Époque, quando a elite carioca procurava imitar o modo de vida europeu, notadamente o de Paris (Cf. NEEDELL, 1993).

Com isso, uma série de mudanças na arquitetura da cidade e no comportamento das pessoas pôde ser notada em função das então conturbadas transições políticas e econômicas, o que possibilitou uma verdadeira revolução na cidade no ínterim dos anos de 1890 a 1922. Como referências de ideias e modelos de concepção artística, muitos conceitos e expressões vindas dos palcos e das obras ficcionais de autores europeus circularam de forma irrestrita no Brasil durante grande parte do século XIX, notadamente na segunda metade, dentre elas o melodrama.

Apesar do escritor Coelho Neto se mostrar avesso às manifestações literárias estrangeiras - por defender um teatro nacional -, ao analisarmos com minúcia sua obra teatral, podemos perceber a reverberação do melodrama em algumas de suas peças como Ironia e $O$ dinheiro, através da utilização de recursos e efeitos melodramáticos que o gênero francês empresta aos textos dramatúrgicos de Neto.

Assim, nos dramas estudados, podemos notar uma inconfundível relação com o excesso de sentimentos, com o exagero das tonalidades emotivas e com o aspecto espetacularizante, próprios do melodrama. Logo, poder-se-ia dizer que um imaginário melodramático instaurou-se como fonte de inspiração e rica referência artística no fim do século XIX, por possibilitar vários artifícios e elementos atraentes em seu conteúdo, passíveis de serem dinamizados em diversos escritos, impregnando a obra de muitos

\begin{tabular}{|l|l|l|l|l|}
\hline Pensares em Revista & São Gonçalo, RJ & n. 1 & $169-185$ & jul.-dez. 2012 \\
\hline
\end{tabular}


escritores, a princípio não tão afins ao gênero, como o escritor Coelho Neto.

É necessário ressaltar o importante projeto dramatúrgico de Coelho Neto no Rio de Janeiro da virada do século, com o objetivo de fazer surgir uma proposta de escrita teatral (e cênica) efetivamente nacionais e procurava entender com seus textos os limites dessa identidade cultural e artística. Ansiando por "renovar" ou "recuperar" o teatro nacional, Neto defendeu fortemente os ideais de um teatro brasileiro de qualidade literária, que falasse ao público carioca da época, retratando-o sob a forma do drama. Devido a este fato, talvez, observou com tanta particularidade os personagens que frequentavam o Rio de Janeiro da belle époque, tornando a cidade e a sociedade fluminenses o palco de suas obras teatrais. Tudo parece muito intenso na obra, que traz em si as nuances do melodramático, com direito a arma escondida, vingança e traições.

Como homem de letras e defensor do teatro, Coelho Neto procurou sensibilizar a opinião pública de sua época com relação ao trabalho dos artistas, à condição de precariedade em que se encontrava o meio artístico no período e à importância da construção de um teatro municipal. Esta preocupação fica evidente na personagem de Julieta em Ironia, papel que a torna uma heroína patética coelhonetiana, cuja dor e sofrimento não deixam de transmutar para a literatura uma inquietação quanto à classe artística daquele momento histórico.

Assim, é mister lançar um novo olhar sobre a obra dramática de Coelho Neto, bastante esquecida e padronizada pela historiografia teatral, buscando uma nova leitura sobre esses textos à luz de outro paradigma, a fim de que estas peças revelem-se não só como obras que dialogam e referem ao seu período histórico, mas que desvelam uma estética peculiar ao teatro praticado na virada do século.

\section{Referências bibliográficas:}

AZEVEDO, Artur. Palestra. O País. Rio de Janeiro, 06 nov. 1898.

BORBA FILHO, Hermilo. História do teatro. Rio de Janeiro: Livraria-Editora da Casa do Estudante do Brasil, 1950.

BRAGA, Cláudia. Os dramas "coelhonetianos". In: NETO, Coelho. Teatro de Coelho Neto: tomo II. Rio de Janeiro: Funarte, 2001.

\begin{tabular}{|l|l|l|l|l|}
\hline Pensares em Revista & São Gonçalo, RJ & n. 1 & $169-185$ & jul.-dez. 2012 \\
\hline
\end{tabular}


BROOKS, Peter. The melodramatic imagination: Balzac, Henry James, Melodrama, and the mode of excess. London: Yale University Press, 1976.

COUTINHO, Júlia Alves. Um projeto de renovação teatral: o Festival do Centro Artístico e o teatro amador em 1898. Dissertação de mestrado. Unicamp, 2009.

DUARTE, Regina Horta. Noites circenses: espetáculos de circo e teatro em Minas Gerais no século XIX. Campinas, SP: Editora da Unicamp, 1995.

FARIA, João Roberto. Ideias teatrais: o século XIX no Brasil. São Paulo: Perspectiva, 2001.

FOUCAULT, Michel. A ordem do discurso. São Paulo: Edições Loyola, 1970.

HUPPES, Ivete. Melodrama: o gênero e sua permanência. São Paulo: Ateliê editorial, 2000.

MATERNO, Ângela. A commedia dell'arte. In: O teatro através da história. Rio de Janeiro: CCBB; Entourage Produções Artísticas, 1994.

MEYER, Marlyse. Folhetim: uma história. São Paulo: Companhia das Letras, 1996.

MERISIO, Paulo Ricardo. Um estudo sobre o modo melodramático de interpretar: o circoteatro no Brasil nas décadas de 1970-1980 como fonte para laboratórios experimentais. 2005. Tese (Doutorado em Teatro) - Programa de Pós-graduação em Teatro, Universidade Federal do Estado do Rio de Janeiro, 2005.

Confluências com o melodrama dos circos-teatros: pantomima, commedia dell'arte e o boulevard du crime. Sala preta, v. 6, n. 1. São Paulo, PPGAC, 2006. http://www.eca.usp.br/salapreta/PDF06/SP06_05.pdf.

NEEDELL, Jeffrey. Belle époque tropical. Rio de Janeiro: Companhia das Letras, 1993.

NETO, Coelho. Teatro de Coelho Neto: tomo II. Rio de Janeiro: Funarte, 2001.

PAVIS, Patrice. Dicionário de teatro. São Paulo: Perspectiva, 1999.

REIS, Ângela. As condições de representação teatral na virada do século. Revista Folhetim, n. 5, out. 1999.

THOMASSEAU, Jean-Marie. O melodrama. São Paulo: Perspectiva, 2005.

Artigo recebido em: 31 de julho de 2012 .

Artigo aprovado em: 30 de setembro de 2012 .

\begin{tabular}{|l|l|l|l|l|}
\hline Pensares em Revista & São Gonçalo, RJ & n. 1 & $169-185$ & jul.-dez. 2012 \\
\hline
\end{tabular}




\section{Sobre a autora:}

Mestranda em Artes Cênicas pela Universidade Federal do Estado do Rio de Janeiro e graduada em Letras (Português-Inglês) pela UERJ (2010). Possui Especialização latosensu em Estudos Literários pela Faculdade de Formação de professores da UERJ em 2012. Graduanda em Direção Teatral pela Universidade Federal (UFRJ). Atualmente é professora de Língua Inglesa da Prefeitura da Cidade do Rio de Janeiro. Membro do grupo de pesquisa "Ressonâncias do Decadentismo na Belle Époque Brasileira". 